\title{
A study of Stress of police constables in Mumbai police stations
}

\author{
Anupama Nerurkar \\ ${ }^{1}$ Head of Department, Department of Commerce, L.S Raheja College of Arts \& Commerce, Mumbai. \\ Corresponding author: Dr. Anupama Nerurkar \\ Email - anupamanerurkar@gmail.com
}

\begin{abstract}
Background: The research paper examines the stressors encountered by the employees in police department and especially police constables. The purpose of the study is to determine if the stress levels are significantly different for different designations and trying to ascertain through interviews the reasons of stress which hinders their performance and the measures taken by Mumbai police department to reduce the stress.

Methods: A random sample of 90 police constables from 10 police stations was selected. The data was collected from self constructed questionnaire and personal interviews. One way ANOVA was done to find if the difference in stress was significantly different in 4 different job designations.

Results: The possible suggestions to reduce stress among police constables that were reached at:Human relations approach, Participative management Healthy superior - subordinate relationship, Better working conditions, effective leadership.

Conclusion:Causes of stress among Mumbai police constables are identified as Long and impossible hours of duty, Tremendous pressure of job, Lack of effective leadership, Arbitrary postings and transfers etc.
\end{abstract}

Keywords: Mental health, Stress, Police constables, Mumbai police.

(Paper received $-4^{\text {th }}$ January 2018, Peer review completed $-10^{\text {th }}$ January 2018)

(Accepted $-12^{\text {th }}$ January 2018)

\section{INTRODUCTION}

Mental health includes our emotional, psychological and social well being. Mental health is important at every stage of life and in every organisation. Unsound mental health can lead to taking extreme step like suicides. It affects thinking, mood and behaviour of the people in the organisation. Police department is not an exception to it. However, the situation is serious. Maharashtra has had the highest number of recorded suicides by police personnel in the past year, according to latest data released by the National Crime Records Bureau. The state recorded 40 cases in 2013. Between 2006 and 2013, the state recorded 267 police suicides.

\section{Objectives of the study -}

1. To identify the reasons for poor mental health of police constables in Mumbai.

2. To review the measures taken by Government to improve their mental health.

\section{Statement of problem -}

Police constabulary is in maximum percentage. They are treated at par with unskilled labourers and 80 percent of them retire in the same rank after serving the police force for 35 years. Experts say that Maharashtra has worst figures because it does not have proper healthcare and accommodation. They are overburdened with inordinate working hours and travel. According to ex-police commissioner Singh, Mumbai police personnel suffer especially due to pressures of urban living in comparison with other states. 
Most police constables in Mumbai live in slums or chawls located far away from the place of duty. With their meagre salaries, it is difficult to bear the cost of living in Mumbai. Thane police Commissioner K.P. Raghuvanshi said, "In many cases, it is not only work stress. Depression is also due to personal and family reasons. The tolerance level of personnel has gone down"

Pastonjee defines Stress as unavoidable. According to Harrison, stress is experienced when there is lack of between his/her environment. Constable, who constitute about 80 percent of the total police force of the country are the most frequently visible police officers and generally first to come in contact with the people. The crux of efficient policing is amiable and effective street presence of a motivated and well trained constable. Long and arduous hours of work with no rest and recreation continuous deployment under extreme conditions of stress and strain, prolong stagnation in the same rank, inadequate pay structure etc. hamper the performance of constabulary. Constables were ill paid, overworked, both by night and day, of little or no education, oppressed with the knowledge that public opinion is prejudiced against them. Police on patrolling has no facility of sanitation, rest and lunch which affects their efficiency[1]. Late R.R. Patil [2], Ex-Minister of state, Home Affairs said that with a 30 percent reservation for women to provide amenities for women police at police stations such as separate washrooms, changing rooms is must. The minister is trying to remove disparity in salary structure, making the police jobs more attractive and prestigious for women. According to the Mumbai study conducted in 2004, on festive days, police force is on the streets rather than celebrating festivals. This means that police officers and other ranks with the commissioners can't avail holidays or leave due to this. For various reasons, police work in 12 hour shifts while the labour law provides for 8 hours shift. In view of the shortage of man power heavy crime work and uncertain law and order duties, policemen have to work for 16 hours at a stretch. They also do not avail weekly holidays, casual leave, earned leave and the other gazetted holidays. As a result, over- worked policemen suffer from stress related diseases like diabetes, high blood pressure, ulcer, heart problems etc. [3]. Another research is a study conducted. (Nagpur rural) revealed that the suicide rate in Maharashtra Police force was 17 per 1 lakh, while the national average was 10.5 per 1 lakh population. This increases the stress among police force in Maharashtra. [4-5]

Public image, unfortunately due to variety of reasons, some of them historical, the police do not enjoy adequate support and confidence of community. The public view the police as the long arm of the state that harasses and no befriends them. Today the police are feared by a common man, misused by the rich and powerful for their selfish ends, piloted by the press and made a scapegoat by the party in power. Harmonious police community relationship in India still remains an unrealized dream. Morals are an outcome of motivation. Police force is often demoralized which in turn affects their performance. Employee's morale is said to be high when they feel, enthusiastic and optimistic about their work, and is said to be low or poor when they are dissatisfied permissive and frustrated with their jobs. Erosion of morale can be said to exist when there are work stoppage, high labour turnover and lack of interest, absenteeism and disciplinary problems. In contrast, the main four attributes of good morale are zeal, discipline, self control and satisfaction [2].

\section{METHODOLOGY}

Procedure - The study is based on primary data. The data required for study is collected from selfstructured questionnaires and personal interviews of the respondents. The researcher has selected a random sample of 90 constables from 10 police stations in Mumbai.

Sample -

\begin{tabular}{|l|l|l|l|}
\hline Sr. No. & Designation & No. & Percentage \\
\hline 1 & Head Constable & 30 & 28.83 \\
\hline 2 & Police Naik & 20 & 26.64 \\
\hline 3 & Police Constable & 30 & 23.76 \\
\hline 4 & Others & 10 & 20.78 \\
\hline & Total & 90 & 100.00 \\
\hline
\end{tabular}


The researcher used one way ANOVA for 4 different samples. The following hypothesis was framed for the purpose of analysing the data.

\section{Design and Hypothesis}

H0- There is no significant difference in stress levels in different designations of police work force (NULL)

\section{RESULTS}

Table 2 - Stress in Work Life as a Whole for Police Constables

\begin{tabular}{|l|l|l|l|}
\hline Sr. No. & Overall stress in the work & $\begin{array}{l}\text { YES } \\
\text { No. }\end{array}$ & $\begin{array}{l}\text { YES } \\
\mathbf{( \% )}\end{array}$ \\
\hline 1 & Quite stressful & 47 & 52.22 \\
\hline 2 & Somewhat stressful & 30 & 33.33 \\
\hline 3 & Moderately stressful & 11 & 12.22 \\
\hline 4 & Relaxed & 2 & 2.23 \\
\hline & Total & 90 & 100.00 \\
\hline
\end{tabular}

Table 1 indicates that about 52.22 percent of the respondents felt that their work life is quite stressful. Out of 90 respondents, 30 said the job is somewhat stressful, 11 felt that it is moderately stressful and only 2.23 said there is no stress. They feel relaxed. The researcher thus concludes that majority of the police constables work under stress which affects the work culture in Mumbai police department.

Table 3 -Reasons for mental stress among Mumbai police constables

\begin{tabular}{|c|c|c|c|c|c|c|}
\hline $\begin{array}{l}\text { Sr. } \\
\text { no. }\end{array}$ & $\begin{array}{c}\text { Statements related to } \\
\text { stress }\end{array}$ & $\begin{array}{l}\text { Never or } \\
\text { rarely } \\
{[\text { No. }(\%)]}\end{array}$ & $\begin{array}{l}\text { Occasionally } \\
{[\text { No. }(\%)]}\end{array}$ & $\begin{array}{l}\text { Sometimes } \\
{[\text { No. }(\%)]}\end{array}$ & $\begin{array}{l}\text { Frequently } \\
{[\text { No. }(\%)]}\end{array}$ & $\begin{array}{c}\text { Very frequently } \\
\text { or always } \\
\text { [No. }(\%)]\end{array}$ \\
\hline 1 & $\begin{array}{l}\text { The job tends to } \\
\text { interfere with my } \\
\text { family life. }\end{array}$ & $\begin{array}{c}15 \\
(17.2)\end{array}$ & $\begin{array}{c}9 \\
(10.92)\end{array}$ & $\begin{array}{c}48 \\
(53.8)\end{array}$ & $\begin{array}{c}10 \\
(11.25)\end{array}$ & $\begin{array}{c}8 \\
(6.84)\end{array}$ \\
\hline 2 & $\begin{array}{l}\text { I hardly get any support } \\
\text { from my superiors. }\end{array}$ & $\begin{array}{c}20 \\
(23.04)\end{array}$ & $\begin{array}{c}10 \\
(12.02)\end{array}$ & $\begin{array}{c}42 \\
(46.64)\end{array}$ & $\begin{array}{c}11 \\
(13.01)\end{array}$ & $\begin{array}{c}7 \\
(5.29)\end{array}$ \\
\hline 3 & $\begin{array}{c}\text { I feel stagnant in my } \\
\text { role. }\end{array}$ & $\begin{array}{c}30 \\
(33.52)\end{array}$ & $\begin{array}{c}9 \\
(10.4)\end{array}$ & $\begin{array}{c}38 \\
(42.15)\end{array}$ & $\begin{array}{c}8 \\
(8.63)\end{array}$ & $\begin{array}{c}5 \\
(5.2)\end{array}$ \\
\hline 4 & $\begin{array}{c}\text { I often feel tensed } \\
\text { because of the nature of } \\
\text { my work. }\end{array}$ & $\begin{array}{c}15 \\
(17.04)\end{array}$ & $\begin{array}{c}11 \\
(11.62)\end{array}$ & $\begin{array}{c}46 \\
(50.44)\end{array}$ & $\begin{array}{c}12 \\
(13.5)\end{array}$ & $\begin{array}{c}6 \\
(7.41)\end{array}$ \\
\hline 5 & $\begin{array}{l}\text { At times I have to do } \\
\text { such things which } \\
\text { lower my self-esteem. }\end{array}$ & $\begin{array}{c}25 \\
(27.49)\end{array}$ & $\begin{array}{c}12 \\
(12.97)\end{array}$ & $\begin{array}{c}41 \\
(45.45)\end{array}$ & $\begin{array}{c}8 \\
(9.42)\end{array}$ & $\begin{array}{c}4 \\
(4.55)\end{array}$ \\
\hline 6 & $\begin{array}{l}\text { Sometimes I cannot } \\
\text { sleep because of the } \\
\text { problems related to my } \\
\text { work. }\end{array}$ & $\begin{array}{c}9 \\
(10.36)\end{array}$ & $\begin{array}{c}12 \\
(13.47)\end{array}$ & $\begin{array}{c}51 \\
(56.57)\end{array}$ & $\begin{array}{c}11 \\
(12.36)\end{array}$ & $\begin{array}{c}7 \\
(7.13)\end{array}$ \\
\hline
\end{tabular}

Table 3 shows reasons for mental stress among police constables. It was found by the researcher that $48 \%$ of the constables feel that sometimes the stress is because of the fact that their job affects their family life. Out of 90 respondents, 42 individuals feel that sometimes the stress is created due to lack of support from the superiors. The stress was created due to the feeling that their role is stagnant which the opinion of 38 constables was. Out of 90 constables, 46 felt that sometimes they feel tensed because of the nature of their work. Whereas, 41 constables felt that the stress comes due the feeling of low self esteem. Fifty-one percent constables were of the opinion that they sometimes cannot sleep because of the problem related to work. 
Table 4 - Mean and Standard Deviation of One-way ANOVA for Total Stress in \% of Police Constables

\begin{tabular}{|l|l|l|l|l|}
\hline Sr. No. & Designation & No. & Mean & Std. Deviation \\
\hline 1 & Head Constable & 276 & 47.9555 & 16.36429 \\
\hline 2 & Police Naik & 182 & 43.2496 & 17.91782 \\
\hline 3 & Police Constable & 226 & 41.5297 & 18.17460 \\
\hline 4 & Other & 204 & 40.4587 & 19.48266 \\
\hline & Total & 888 & 43.6334 & 18.12413 \\
\hline
\end{tabular}

Table 5 - Mean and Standard Deviation of One-way ANOVA for Total Stress in \% of Police Constables

\begin{tabular}{|l|l|l|l|l|}
\hline Sr. No. & Designation & No. & Mean & Std. Deviation \\
\hline 1 & Head Constable & 276 & 47.9555 & 16.36429 \\
\hline 2 & Police Naik & 182 & 43.2496 & 17.91782 \\
\hline 3 & Police Constable & 226 & 41.5297 & 18.17460 \\
\hline 4 & Other & 204 & 40.4587 & 19.48266 \\
\hline & Total & 888 & 43.6334 & 18.12413 \\
\hline
\end{tabular}

Table 6 - ANOVA Table for Comparison of Stress Level among Police Constables based on the Designation

\begin{tabular}{|l|l|l|l|l|l|}
\hline & Sum of Squares & df & Mean Square & F & Sig. \\
\hline Between Groups & 8238.854 & 3 & 2746.285 & 8.575 & .000 \\
\hline Within Groups & 283126.617 & 884 & 320.279 & & \\
\hline Total & 291365.471 & 887 & & & \\
\hline
\end{tabular}

Reasons / causes identified for increased stress level among police constables

From the primary data collected through the questionnaire and interviews, the findings were as follows.

1. Frequent judicial, departmental and magisterial enquiry - Mental health among police personnel is adversely affected by time consuming and delayed procedures for enquires at various levels leading to punitive actions like dismissal / removal / suspension from services.

2. Human rights charges by members of public - Implementation of morale policing itself is a controversial issue in India with number of ethical, cultural and religious issues. Police constables on streets, festival gatherings, parks and beaches or in police stations experience low morale due to interference of human rights activists and political parties. Recently, the custodial deaths are a serious issue.

3. Long and impossible hours of duty - There are no fixed hours of work for police constables as they are in-charge of a particular case / Nakabandi / security of VIP/ communal riots/accidents/crimes/festivals/elections/night duties and even important examinations. Irregular and long working hours leads to poor physical health affecting mental health. Due to these, they often fall prey to alcoholism and tobacco which affects physical and mental health.

4. Tremendous pressure of job - The nature of police job is related with maintenance of law and order, which itself creates pressure in Mumbai with huge cosmopolitan population, problem of urbanisation and huge rate of crime.

5. Lack of social status - Unfortunately especially police constables lack social status.In olden days, police was looked as a friend of public. The scenario is changing due to number of reasons.

6. Absence of vertical mobility in career planning - Career planning and development is an essential element of human resource development which is lacking in the case of police 
constables. They wait for the promotions for several years or get retired on the same position as a constable.

7. Distorted schemes of rewards and punishments - In police department there are more punishments than rewards which demotivates the constables.

8. Lack of effective leadership - The leaders is not only police commissioners, DCP, ACP but immediate bosses at police stations like PSI and ASI. It has been proved in the past history of police department that majority of police constables are loyal and follow the orders of their superiors without the fear of their life. Leaders influence their life to great extent. Many unfortunate events have occurred where constables have shot their superiors indicating their poor mental health.

9. Arbitrary postings and transfers - This policy has also created adverse effect on their life. Most of the transfers are politically influenced leading to corruption.

10. Political Interference - As all government departments have political influence, police is not an exception to this. The actions of police stations are often influenced by not only state ministers but even local politicians directly or indirectly.

11. Communication gap - Majority of the police constables are either illiterate or from rural area in Maharashtra with main communication in Marathi. While dealing with cosmopolitan public, it often becomes a barrier leading to low self esteem and bad public image.

12. Staying away from the family and children - The transfers in police department can be even in a remote area in Maharashtra which does not have social infrastructure for their families like education and health. They are forced to live far from their family leading to poor mental health.

13. Severe injury / loss of limb - For the police services which are defence services, it is very common to have injuries many times serious in nature while fighting with criminals. It affects physical as well as mental health in a negative way.

14. Death of colleague on duty - Such unfortunate situations lead to low morale among police constables.

15. Treatment by superiors - Ill treatment by superiors also results in mental imbalance.Trained constables are working with IPS officers as their personal servants doing house chores.

16. Poor working conditions at police stations and beats - Majority of the police stations lack good infrastructure and basic facilities like sanitary and water. This results in sickness.

Other reasons include favouritism, nepotism, corruption and violence of departmental rules in carrying out one's duties. Erosion of police morale has resulted in the fall of standards of police performance and increase in complaints against them. It results in police ineffectiveness. Good work, sincerity and good discipline have no more consideration for promotion.

\section{CONCLUSIONS}

The suggestions to improve poor mental health among police constables -

1. Human relations approach: Basically sound human resource policies are absent in police department resulting in improper human relations. Treating constables as human beings by superiors and not as numbers (generally allotted to them) is one effective method to increase their morale.

2. Participative management: Constables feel that their job is only to follow superior's orders. Participative management involves delegation of authority and responsibility to constables. This will motivate them, train them on the job as well as the experienced constables can share their expertise.

3. Job enlargement and enrichment: Opportunities for promotion is very important which will distinguish competent and incompetent constables. Promotion by merit will help in overcoming mental problems.

4. Healthy superior - subordinate relationship: Police constables know how to use weapons. But many times they use it for killing themselves or their superiors. Many superiors are able to build 
teams of devoted constables due to their working styles and successfully fought against the crimes in their local areas.

5. Restructuring of training: Effective training should not only include physical training but building emotional quotient to handle disastrous situations. Emotionally balance constables will be able to cope up with worst situations.

6. Effective leadership: As said earlier, police department, being government wing has autocratic style of leadership. In the changing scenario, it should be participative and transformational.

7. Better working conditions: Working hours is a prime concern which takes toll on the life of constables. Meanwhile new commissioner has tries to execute 8 hours duty and it was also implemented at various police stations. However the nature of job does not permit its successful implementation. Good infrastructure including water, sanitary and canteen facilities will take care of their physical as well as mental health. Also conditions of their houses in Mumbai are pathetic.

8. Time management: Due to long working hours, constables are not able to balance their work-life. Though many police stations are taken good imitative to start gyms, constables hardly get time to join for their personal physical fitness.

9. Networking regular vacations: Where taking weekly off is a problem due to the pressure of work, their leaves also get cancelled due to emergency situations.HR policies should be framed in such a way that all vacancies are filled up and all constables should get a right to go on vacations.

10. Psychological up gradation like Enhanced self esteem and awareness: Positive thinking, Self development, Goal setting, Meditation, Holistic yoga exercises, Mind stilling practices, Medication and other relaxation as individual stress coping mechanism through camps and workshops are recommended.

At organisational level, the following strategies may help - Programme for spouses, Counselling, Job rotation, Revamping of criminal justice system, Appreciation, Psychological screening of new entrants, Effective grievance redressal machinery etc.

The National Police Commission's first report has suggested ways and means of raising the morale of constables by improving service conditions and the working environment. It suggested mandatory judicial enquiry and not by higher rank for complaints against police.

The police morale will remain unsure and self respect brittle if the public attitude towards the police information by the press remains constantly critical. Police employees including the police constables are expected to follow certain codes of conduct which create work culture of the police department. In Maharashtra and thereby Mumbai police, it is not allowed to form a police union. In other words, in Maharashtra, police union is not allowed after 2004. Thus, many constables feel that their rational demands are not met and they are provided with secondary treatment as compared to other government departments. Fair treatment in terms of remuneration, working conditions and treatment by superiors is what is required to improve present work culture. All respondents said that the union does not exist.

\section{REFERENCES}

1. Cox EC. Police and crime in India. S. Paul \& co.; 1911.

2. Datta P, Pati B, Sarkar S, Sarkar T, Sen S. Understanding communal violence: Nizamuddin riots. Economic and political weekly 1990;10:2487-95.

3. Umranikar JY. Police Reforms in India. A Sisyphean Saga, Functional Review of India Police, A step towards good governance, Ameya Prakashan, Pune. 2009.

4. Suresh K. Mumbai Jalali Bhivandi ka nahi. Sneha Prakashan, Pune. 2010.

5. Patil Satej. Saying it with sweets to strengthening security. Protector [Feb 2011]. 2(3); 34-35.

$* * * * * * * * * * * * * * * * * * * * * * * * * *$

Acknowledgements - Nil

Conflict of Interest - Nil; Funding - Nil

Indian Journal of Mental Health 2018;5(1) 